Journal of Applied Biology \& Biotechnology Vol. 4 (04), pp. 090-096, July-August, 2016

Available online at http://www.jabonline.in

DOI: 10.7324/JABB.2016.40411

(c) BY-NC-SA

\title{
Selection of some fungal pathogens for biological control of Trianthema portulacastrum L., a common weed of vegetable crops
}

\author{
Gaddeyya Gandi Pilli ${ }^{*}$, P. K. Ratna Kumar ${ }^{1}$, Bharathi Pilaka ${ }^{2}$ \\ ${ }^{1}$ Department of Botany, Andhra University, Visakhapatnam 530003, A.P., India. \\ ${ }^{2}$ Govt. Degree, College, Chodavaram, Visakhapatnam-530003, A.P., India.
}

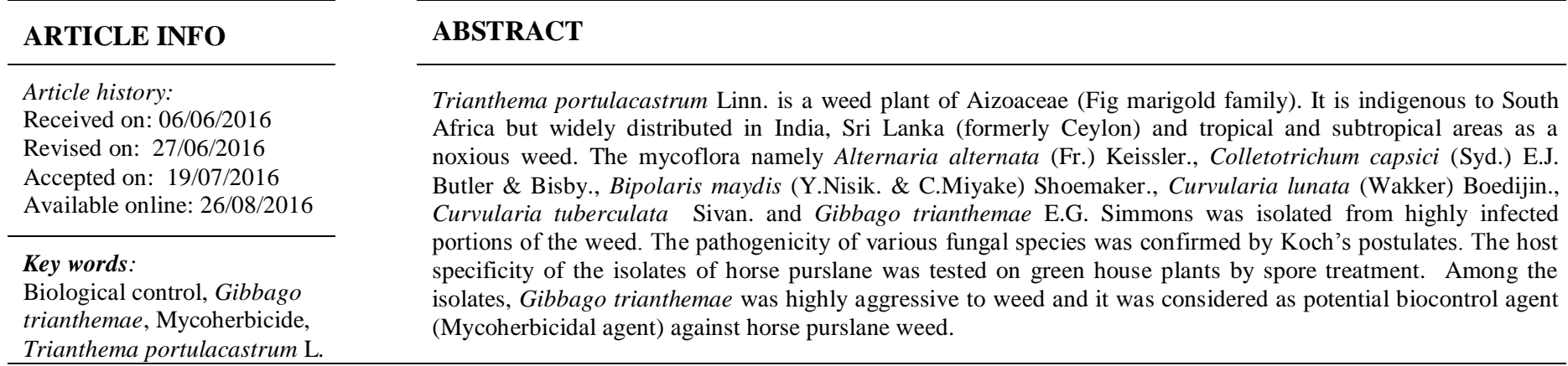

\section{INTRODUCTION}

Trianthema portulacastrum L. (common name: horse purslane; family: Aizoaceae) is a branched, prostrate, succulent, annual herb indigenous to South Africa but is widely distributed in Northern India and several other tropical and subtropical areas including Sri Lanka, West Asia, Africa and Tropical America as an invasive weed of cultivated fields and wastelands [1-5]. It is considered as a major weed in various food and vegetable crops such as Brassica sp. (Mustard), Zea mays L. (Corn), Cajanus cajan (L.) Millsp. (Pigeonpea), Glycine max (L.) Merr. (Soybean), Solanum lycopersicon L.(Tomato), Solanum tuberosum L. (Potato), Allium cepa L. (Onion) and Gossypium hirsutum L. (Cotton).

It has become a noxious weed due to competition for yields in many crops like Pennisetum glaucum L. (Millet), Sorghum bicolor L. (Sorghum), Zea mays L. (Maize), Triticum aestivum L. (Wheat), Vigna mungo L. (Mash bean), Vigna radiata L. (Mungbean), Cyamopsis tetragonoloba L. (Guar or cluster bean) and Helianthus annuus L. (Sunflower) and causing significant reduction in the yield [6]. The severe infestation of weed has been reported in pigeon pea and soybean (60-70\%) and

\footnotetext{
* Corresponding Author

Email:mycology.au@gmail.com
}

Maize and Brassica fields (80- 90\%) [7]. Horse purslane is a harmful weed infested in many crops like brinjal, okra and other vegetables. The control of horse purslane in field crops is very essential due to the increase of loss in yield of many crops in every year and also many farmers depended on these food and vegetable crops for their economy. Horse purslane is currently controlled by mechanical methods and also the application of herbicides such as acifluorfen, alachlor, atrazine, bentazon, fluchloralin, fomesafen, paraquat and pyrivate. But in view of pesticide residues and environmental pollution, the exploitation of microorganisms especially plant pathogenic fungi is now emerging as an effective and eco-friendly alternative to conventional methods of weed management [8]. Mycoherbicides are attractive agents in weed management because of their specificity, low environmental impact and cost effective [9-10]. Many kinds of pathological symptoms on T. portulacastrum at field condition reported by a systematic epidemic study conducted at agricultural fields of Visakhapatnam District during 2012-2013. The weed population in natural conditions was extensively suppressed by natural enemies such as fungal pathogens which cause foliar symptoms like leaf spots, leaf blights, necrosis and defoliation. Moreover, the wilting of stems was observed at mature stage of various symptoms. In view of the above, the research was aimed to screening of mycoflora and their pathogenesis against horse purslane weed towards selection of a potent mycoherbicide agent. 


\section{MATERIALS AND METHODS}

\subsection{Field study and sample collection}

The field observations on infestation of horse purslane were conducted in different agricultural crops classifieds as food crops, pulses, vegetable crops, oil seed crops and commercial crops at Vishakhapatnam District. The weed infestation was studied using random sampling method in all agricultural fields and some valuable information about the weed infestation was gathered from local farmers. The infected leaves and various symptoms on horse purslane were critically studied during 20122013 at field sites and photographs of diseased leaves and whole plants were taken using digital camera (Nikon Coolpix S6700 20.1MP). The diseased plants and propagules were collected randomly into sterilized polythene bags and brought to the laboratory for the extensive study on symptoms, isolation and virulence of the organism (s) involved in pathogenesis. The disease symptoms on leaves and stems and other plant parts were critically examined in plant pathology laboratory, Department of Botany, Andhra University, Visakhapatnam.

\subsection{Screening of mycoflora}

\subsubsection{Culture of parasitized leaf bites}

The diseased leaves were washed thoroughly in running tap water to remove soil particles and the infected portions of the leaves were cut into 1.0 to $1.5 \mathrm{~cm}$ fragments. The pieces were surface sterilized by $70 \%$ ethyl alcohol for 1-2 minutes and then rinsed in sterile distilled water for three to four times. Finally the leaf bits were rinsed in $0.01 \%$ mercuric chloride for 1 or 2 minutes followed by washing with sterile autoclaved double distilled water for 2 or 3 times. These fragments were transferred on to Czapek's Dox Agar (CDA) and Potato dextrose agar (PDA) plates supplemented with 1\% streptomycin sulphate (antibiotic) under sterile conditions in an inoculation chamber. After inoculation plates were incubated at $25 \pm 2{ }^{\circ} \mathrm{C}$ for 21 days under a $12 \mathrm{~h}$ light/dark photoperiod [11].

\subsubsection{Isolation and identification of fungal pathogens}

The isolates were purified during the initial growth of fungal colonies on inoculated leaf lesions on the surfaces of agar media. The stock cultures of the isolates were prepared using mono culture (single conidial culture) and stored at room temperature as slant cultures on PDA media. The isolates were examined by the staining techniques and diagnostic characteristics of the isolates were examined under light microscope. The identification features of each isolates such as colony diameter, colour, texture, sporulation, secondary metabolites, the shape and sizes of conidiophores and conidia were carefully studied. Identification of the fungal isolates was made with help of the relevant literature [7, 12-24].

\subsection{Preparation of spore inoculum for pathogenicity study:}

Spore inocula of isolates were harvested from fresh young, sporulated cultures incubated at $25 \pm 2^{\circ} \mathrm{C}$ with a $12 \mathrm{~h}$ light/dark photoperiod. Conidia and mycelium production were carried out on young sporulated cultures of the isolates in aseptic conditions. The finest spore inocula (104- 106 spores $/ \mathrm{ml}$ ) were made using sterilized spatula by flooding the plates with sterile 20 $\mathrm{ml}$ distilled water and then scraping the mycelial mass slowly for conidial suspension. Afterthat, the suspension was filtered through sterile, muslin cloth folded in four layers and the final inoculum was taken into $100 \mathrm{ml}$ conical flasks containing sterile distilled water mixed with $0.02 \%$ (v/v) Tween 20 (Merck), the wetting agent. The inoculum concentration was adjusted to $1 \times 104$ to $5 \times 104$ spores/ml using Improved Neubauer haemocytometer $(0.1 \mathrm{~mm})$.

\subsection{Maintenance of test plants (weed) in green house conditions}

Seeds and seedlings of horse purslane ( $T$. portulacastrum) were collected from agricultural fields during the field study. The collected seeds were dried and maintained in healthy condition without any contamination. The plants for further studies were grown by sowing the seeds in $25 \times 15 \mathrm{~cm}$ diameter plastic pots containing sterilized black soil. The pots containing seedlings of weed plants were maintained at $25-30^{\circ} \mathrm{C}$ on wood stand in a green house with a $12 \mathrm{~h}$ light/dark photoperiod. For host range studies test plants were maintained in five replicates (10 plants for each replicate) along with control plants. The test plants growing in aseptic greenhouse conditions were watered at healthy conditions. Infected plants observed at pre-inoculation stage were avoided from pathogenicity test. The test plants with healthy, young and greenish leaves were used for the spore inoculation of the fungal isolates.

\subsection{Disease intensity (DI)}

The intensity of infection was determined visually based on the initiation of disease and increase in disease area on the leaves and stems of the test plants every day. Spore inoculum was applied onto the test plants of Trianthema portulacastrum within 2 hours of sunset to avoid drying and to allow for a natural dew period shortly afterwards. Plants were observed three days after treatment (DAT) for disease symptoms. The intensity of infection was determined visually based on the number of infected leaves or area of infected parts or whole plants.

The disease intensity on leaf surfaces and the development of symptoms were observed daily. The disease intensity of pathogens on test plants was determined using a score chart (0 -No infection; $1-0.1$ to $5 \%$ leaf area affected ; 2 - 5.1 to $15 \%$ leaf area affected ; 3 - 15.1 to $30 \%$ leaf area affected ; 4 30.1 to $50 \%$ leaf area affected ; $5-50.1$ to $100 \%$ leaf area affected) [25]. The percent disease index of various fungal species was calculated using the following formula [26]

Per cent Disease Index $\quad(\mathrm{PDI})=$

Sum of all disease ratings X 100

Total number of ratings $\mathrm{X}$ Maximum disease grade 
Table 1: Fungi isolated from infected parts of Trianthema portulacastrum $\mathrm{L}$.

\begin{tabular}{lc}
\hline \multicolumn{1}{c}{ Fungus Name } & Isolated part \\
\hline Alternaria alternata (Fr.) Keissler. & Leaf \\
Bipolaris maydis (Y.Nisik. \& C.Miyake) Shoemaker. & Leaf \\
Curvularia lunata (Wakker) Boedijin. & Leaf \\
Curvularia tuberculata Sivan. & Leaf \\
Colletotrichum capsici (Syd.)E.J.Butler \& Bisby & Leaf \\
Gibbago trianthemae E.G. Simmons (1986) & Leaf, stem \& petiole \\
\hline
\end{tabular}
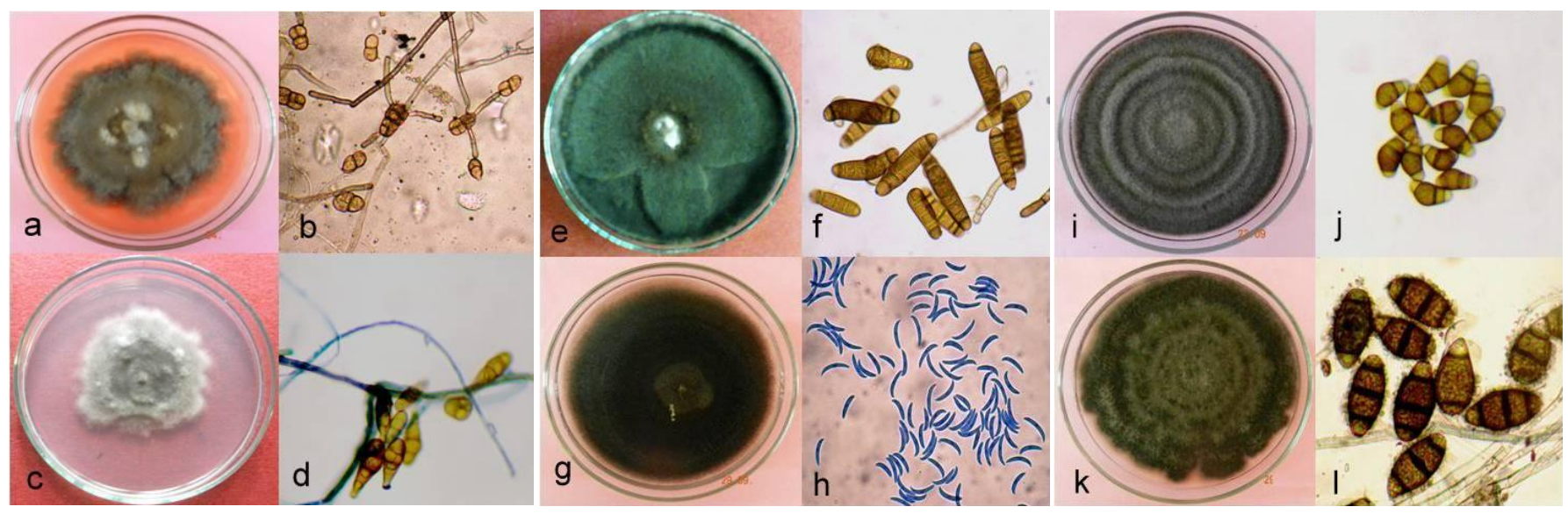

Fig. 1: Macro and microscopic features of fungal isolates of horse purslane (a\&b) Gibbago trianthemae (c\&d) Alternaria alternata (e\&f) Bipolaris maydis (g\&h) Colletotrichum capsici (i\&j) Curvularia lunata (k\&l) Curvularia tuberculate.

\section{RESULTS AND DISCUSSION}

T. portulacastrum, a common weed of many agricultural crops is widely distributed in several regions of the India and Sri Lanka. It has several local names such as Desert Horse Purslane, Giant pigweed (English), Chiratika, Dhanapatra (Sanskrit), Salsabuni, Sabuni, Svetsabuni, Vishakhapara(Hindi), Muchchugoni (Kannada), Ambatimadu and Galijeru (Telugu). In field study, the natural infection on horse purslane leaves and stems were observed in various locations of field area. The typical fungal symptoms on parasitized parts of the horse purslane were noticed. The symptoms on leaf surfaces were examined as leaf spots, leaf blights, necrosis and defoliation. Moreover, the wilting of stems was observed at mature stage of various symptoms caused by fungal pathogens.

\subsection{Fungal species associated with horse purslane}

Foremost, in laboratory conditions the pathogens were isolated from leaf lesions of naturally infected horse purslane plants. A total of six isolates namely Alternaria alternata (Fr.) Keissler., Colletotrichum capsici (Syd.) E.J. Butler \& Bisby., Bipolaris maydis (Y.Nisik. \& C.Miyake) Shoemaker., Curvularia lunata (Wakker) Boedijin., Curvularia tuberculata Sivan. and Gibbago trianthemae E.G. Simmons (1986) were identified in cultures of horse purslane parasitized leaf bits (Table 1).

\subsubsection{Macro and microscopic features of the isolates}

The macroscopic characteristics such as colony diameter, colour, texture, and sporulation observed by culture plate technique while the microscopic characteristic of each isolate was studied using different features of conidiophores, conidia and fruit bodies, and spore germination under light microscopy (Fig 1).

\subsubsection{Alternaria alternata (Fr.) Keissler.}

The fungus produced profuse mycelial growth on PDA. Initially the mycelium was hyaline that turned to grey- brownish, multicelled, septate and irregularly branched. In early growing stage hyphae were thin, narrow, and hyaline but became slightly thick as they grew old. Conidiophores arised singly or in clusters, usually 2-6 and were long or short. They were pale olivaceous to olivaceous - brown, straight or curved, geniculate, slightly swollen at apex having terminal scars indicating the point of attachment of conidia. The length of the condium was 3-5 times more than its width. Conidia were in chains, light olivaceous to dark brown, septate, muriform and measured $47.16 \times 13.49 \mu \mathrm{m}$. Conidia were born in chains up to 10 or more on conidiophores. They were light olivaceous to dark brown in colour, varied in shape from obclavate to mostly ellipsoidal, muriform having tapered apex with 1 to 3 longitudinal and 2-10 transverse septa. The chlamydospores were formed in the old culture of A. alternata. They were intercallary, thick walled, roundish to oval in shape, dark brown in colour.

\subsubsection{Colletotrichum capsici (Syd.) E.J.Butler \& Bisby.}

The isolate was identified based on size and shape of conidia. Isolate produced cottony colonies on PDA with a colour of greyish - to dark grey on the ventral surface whereas the reverse of the colonies was mainly black. The colony diameter ranged from 65 to $70 \mathrm{~mm}$ after 10 days incubation. Conidia uniform with both their ends pointed. Colonies on PDA at first white and becoming greyish with age, reverse greyish - green, attaining 85 
mm radial in 14 days. Aerial mycelia white to grey. Acervuli dark brown to black; setae conspicuous and dark; Conidiophores unicellular, hyaline, cylindrical, phialidic, septate, sometimes branched, tapered towards the apex, $20 \mu \mathrm{m}$ long and $3 \mu \mathrm{m}$ wide. Conidia formed in white masses, one- celled, smooth walled, hyaline, falcate, tapering towards each end with acute apex and truncate base.

\subsubsection{Bipolaris maydis (Y.Nisik. \& C.Miyake) Shoemaker.}

Colonies appeared black to greyish black in PDA; conidia relatively long and broad with dark brown colour, slender and slightly curved; Conidiophores brown, producing conidia through an apical pore and forming a new apex by growth of the subterminal region; conidia fusoid, straight or curved, germinating by one germ tube from each end; exosporium smooth, rigid, brown; endosporium hyaline, amorphous, separating cells of mature phragmospores; bipolaris has indeterminate conidiophores which extent sympodially producing a succession of dark, transversely septate, porospores. These are basically fusoid in shape and germinate only from the ends. The identification features of the isolates include the shape and colour of conidiophores and conidia. Conidiophores mid - to dark brown in colour, medium to long, commonly long, slender, straight or curved, single or in groups of 2 or 3, pale near the apex, smooth, up to $700 \mu \mathrm{m}$ long, and 5-10 $\mu \mathrm{m}$ thick, and bear conidia at wide intervals. Conidia are distinctly curved, broad in the middle, sharply tapering towards rounded ends, pale to mid-dark golden brown, smooth, 5-11 septate, mostly 70-160 $\mu \mathrm{m}$ long, 15-20 $\mu \mathrm{m}$ thick in the broadest part; and point of attachment is dark, often flat, and 3-5 $\mu \mathrm{m}$ wide. Pseudothecia contain asci with four slender, thread-like, 5-9 septate ascospores $(6-7 \times 130-340 \mu \mathrm{m})$ arranged in parallel coils. Pseudothecia rarely occur under natural conditions. The identical features of the isolates include colonies with fast-growing, fluffy, with concentric rings. Conidiophores single or often in groups from flat, dark brown to black stromata, straight to flexuous, septate, smooth, geniculate, mid to dark brown, paler towards the apex, up to $700 \mu \mathrm{m}$ long, 5 to $10 \mu \mathrm{m}$ thick . Conidiogenous nodes verruculose. Conidia distinctly curve, fusoid, pale to mid dark golden brown, smooth, 5-11 - distoseptate, 70 to $160 \times 15$ to $20 \mu \mathrm{m}$, hilum 3 to $4.5 \mu \mathrm{m}$ wide.

\subsubsection{Curvularia lunata (Wakker)Boedijin.}

Colonies blakish brown; stroma simple or branched; pesudothecia black, globose, usually forming on a columnar basal stroma or a flattened crust, 500 - $720 \mu \mathrm{m}$ long, 400 - $490 \mu \mathrm{m}$ wide, beaked with a conical trunkcate beak up to $300 \mu \mathrm{m}$ high, 115-140 $\mu \mathrm{m}$ wide at the base, often hairy in the globose part, hairs septate, simple, brown; aci cylindrical, short- stalked, wall not stained with lactophenol cotton blue, bitunicate,17-130 × 12-13.5 $\mu \mathrm{m}, 2-8$ spored; ascocarpes filiform, hyaline, helically coiled in the ascus and straightening at one or both ends, tapering at both ends, more at the base, sometimes with truncate base, mucilaginous, sheath up to $4 \mu \mathrm{m}$ thick. Conidiophores maco or mononematous, unbranched, terminal, often geniculate above, sympodial, cylindrical; conidia acropleurogenous, straight, ovoid, obclavate or ellipsoidal, unequal sides or rarely with slight curvature, 3-5 mostly 3 - septate, middle calls darker, end cells subhyaline to pale or dark brown, mature conidia tuberculate, 23-52×13-20 $\mu \mathrm{m}$, young conidia subhyaline and smooth walled. The diagnostic features of the isolate observed in culture include the colour and shape of the isolate. The distinguished characteristics of the isolate : Conidiophores arise singly or in groups, simple or rarely branched, straight or sometimes geniculate near the apex, brown to dark brown, multiseptate, variable in length, up to 5-6 $\mu \mathrm{m}$ diameter. Conidia are mostly 3-distoseptate, ellipsoidal to fusiform, or often disproportionately enlarged in the third cell and markedly geniculate or hook-shaped, pale to somewhat colored, almost concolorous, 17-32 × 7-12.5 $\mu \mathrm{m}$, and smooth.

\subsubsection{Curvularia tuberculata Sivan.}

Colonies on PDA dark gray, usually zonate; Colonies on natural substrate effused, brown to black, hairy; mycelium on natural substrate usually immersed; hyphae branched, septate, colorless or brown, smooth or verrucose; stromata often large, erect, black, cylindrical, sometimes branched. Conidia acropleurogenous, sometimes in whorls, arise through pores in the conidiophore wall, straight or curved, usually broadly fusiform, ellipsoidal, obovoid, clavate or pyriform, sometimes rounded at the base, sometimes with a distinctly protuberant hilum, septate, often with one or more cells larger and darker than the others, smooth or verrucose. The diagnostic features of the isolate : Conidiophores arise singly or in groups, terminal or lateral on hyphae, stromata, and ascomata, simple or branched, straight or flexuous, smooth, pale to mid-brown, septate, up to $300 \mu \mathrm{m}$ long, 2-7 $\mu \mathrm{m}$ thick. Conidia are straight, ovoid, obclavate or ellipsoidal, 3-5 (sometimes 8, but mostly 3) septate, intermediate cells brown to dark brown, end cells subhyaline to pale or dark brown, mature conidia tuberculate, 23-52 × 13-20 $\mu \mathrm{m}$. Young conidia are smooth and subhyaline. First septum in the conidium is usually median, second septum often delimiting the basal cell but variations in septal formation may occur. Germination is both by bipolar and lateral germ tubes.

\subsubsection{Gibbago trianthemae E.G. Simmons}

Subsurface mycelia growth was dense and dark on PDA, and inconspicuous on TWA. Sporulation was excellent at agar surfaces of Czapek Dox Agar and the moderate amounts of sporulation appeared on PDA with woolly aerial mycelium. Conidia produced in culture were characterized by means of secondary conidiophores. Conidiophores simple or 1-2 proliferated. 1-4 transeptate, pale straw- colored, up to $60-80 \times 5-6$ $\mu \mathrm{m}$, very slightly swollen at apex, producing a solitary conidium at the apex of each proliferation, retaining a distinct umbilicate or crateriform depression at the conidiogenous locus after secession of conidium. Conidia initially solitary, almost perfectly ellipsoid; becoming broadly ellipsoid to broadly sub ovate -ellipsoid, with 14 complete or partial transverse septa ( slightly constricted at initial median septum), 2 complete longitudinal septa intersecting 
at right angles in each conidium half, plus a few shorter ones in transverse sectors of the conidium; clear pale yellow-brown, smooth; with a minute basal pore-scar that is difficult to observe and that lacks any sort of complex surrounding structure or halo of pigmentation; commonly maturing at about $35-45 \times 15-22 \mu \mathrm{m}$ with 1-4 of the apical cells; enlarging slightly and each giving rise directly to a single secondary conidium morphologically identical with primary conidia; individual apical (sometimes basal) cells also sometimes giving rise to conidiophores that have the distinctive apically swollen and umbilicate appearance of hyphal conidiophores and that are about $7 \times 6 \mu \mathrm{m}$.

\subsection{Pathogenesis of the isolates}

An in vitro test was carried out to confirm the pathogenicity of isolates on horse purslane plants growing in green house conditions (Table $2 \& 3$ ).

Table 2: Pathogenicity of isolates on horse purslane weed after spore treatment

\begin{tabular}{lclc}
\hline $\begin{array}{c}\text { Fungal } \\
\text { Species }\end{array}$ & Score & \multicolumn{1}{c}{ Disease intensity } & $\begin{array}{c}\text { Symptoms } \\
\text { appeared }\end{array}$ \\
\hline $\begin{array}{l}\text { Alternaria } \\
\text { alternata }\end{array}$ & 2 & $\begin{array}{l}\text { Moderate symptoms, } \\
\text { plant showing bigger } \\
\text { patches on 10 - 15\% of } \\
\text { leaf area }\end{array}$ & $\begin{array}{c}\text { Minute } \\
\text { leaf spots } \\
\text { \& necrosis }\end{array}$ \\
\hline $\begin{array}{l}\text { Bipolaris } \\
\text { maydis }\end{array}$ & 1 & $\begin{array}{l}\text { Mild symptoms, plant } \\
\text { showing slight } \\
\text { symptoms on 5\% of the } \\
\text { leaf area }\end{array}$ & $\begin{array}{c}\text { Minute } \\
\text { leaf spots }\end{array}$ \\
\hline $\begin{array}{l}\text { Curvularia } \\
\text { tuberculata }\end{array}$ & 0 & $\begin{array}{l}\text { No symptoms, healthy } \\
\text { plant }\end{array}$ & $\begin{array}{c}\text { No } \\
\text { symptoms }\end{array}$ \\
\hline $\begin{array}{l}\text { Colletotrichum } \\
\text { capsici }\end{array}$ & 0 & $\begin{array}{l}\text { No symptoms, healthy } \\
\text { plant }\end{array}$ & $\begin{array}{c}\text { No } \\
\text { symptoms }\end{array}$ \\
\hline $\begin{array}{l}\text { Gibbago } \\
\text { trianthemae }\end{array}$ & 0 & $\begin{array}{l}\text { No symptoms, healthy } \\
\text { plant }\end{array}$ & $\begin{array}{c}\text { No } \\
\text { symptoms }\end{array}$ \\
\hline
\end{tabular}

Table 3: Mycoherbicide efficiency of fungal species on horse purslane weed in terms of percent disease index.

\begin{tabular}{|c|c|c|c|}
\hline Fungal Species & $\begin{array}{l}\text { Spore Treatment } \\
\text { (Inoculum } \\
\text { Conc.) }\end{array}$ & $\begin{array}{c}\text { Days } \\
\text { After } \\
\text { Treatment }\end{array}$ & $\begin{array}{c}\text { Percent } \\
\text { Disease } \\
\text { Index }\end{array}$ \\
\hline Gibbago trianthemae & $5 \times 104$ spores $/ \mathrm{ml}$ & $\begin{array}{l}30 \\
40\end{array}$ & $\begin{array}{l}82.4 \\
92.9\end{array}$ \\
\hline Alternaria alternata & $5 \times 104$ spores $/ \mathrm{ml}$ & $\begin{array}{l}30 \\
40\end{array}$ & $\begin{array}{l}37.5 \\
45.7\end{array}$ \\
\hline Bipolaris maydis & $5 \times 104$ spores $/ \mathrm{ml}$ & $\begin{array}{l}30 \\
40\end{array}$ & $\begin{array}{l}33.7 \\
43.1\end{array}$ \\
\hline
\end{tabular}

The test plants inoculated with spore concentrations (5x104 spores $/ \mathrm{ml})$ of each isolate of fungal species were examined at $24 \mathrm{~h}$ after the spore treatment. The disease intensity was measured in terms of disease intensity and the results were analyzed. The isolates namely A. alternata and Bipolaris maydis produced moderate symptoms on leaves of horse purslane at $5 \mathrm{~d}$ after inoculation. The phaeodictyoconidial fungus $G$. trianthemae infected extremely on leaves and stems of the test plants and produced typical symptoms which were similar to field observations. The fungal pathogen $G$. trianthemae was reisolated from the infection areas of the inoculated plants and the pathogenicity of the isolate was confirmed on host plant. The remaining isolates namely $C$. capsici, $C$. lunata and $C$. tuberculata considered as non-pathogenic to horse purslane which were failed to produce disease symptoms and eliminated from epidemic studies. $G$. trianthemae, the foliar fungal pathogen of horse purslane was harvested from maroon coloured lesions inoculated on the surface of the growth media. After green house experiments (spore treatments) by using $5 \times 10^{4}$ spores/ $\mathrm{ml}$ inoculum, the pathogen infected the inoculated leaves and pathological symptoms appeared after 3-4 days of spore treatment. Initially symptoms were pin-point, with maroon margins up to 1 $\mathrm{mm}$ in diameter. The lesions became sunken and cause necrosis after 7-9 days of inoculum spraying. The infected leaves became chlorotic followed by defoliation very soon (Fig $2 \& 3$ ).

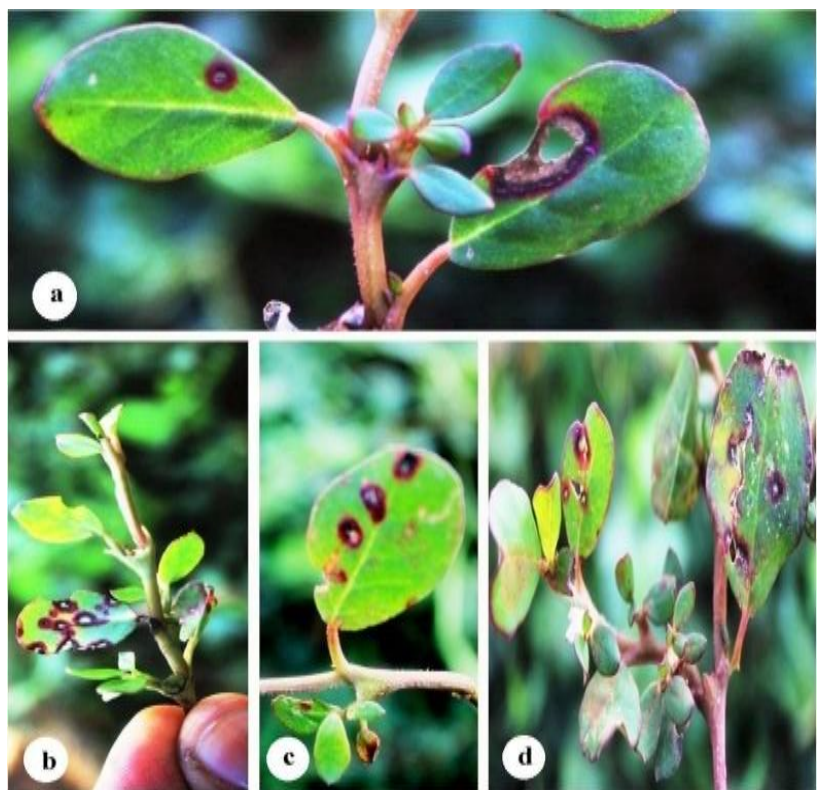

Fig. 2: Severity of leaf spot disease of horse purslane caused by Gibbago trianthemae at field locations

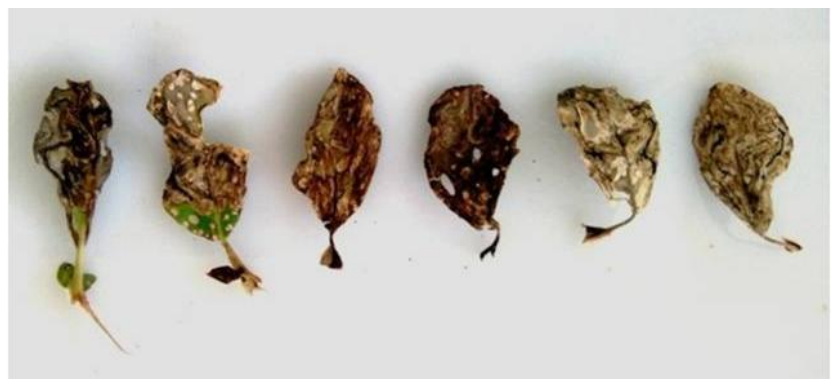

Fig. 3: Mycoherbicidal potential of Gibbago trianthemae on horse purslane after spore treatment (30DAT) at in vitro condition.

Under severe attack quite similar lesions were also examined around the stems causing withering. In earlier, the pathogenesis of $G$. trianthemae on horse purslane was reported by various workers. However, the evolution of mycoherbicide properties of the isolate G.trianthemae not reported widely excluding in USA and India [7, 21-24]. Most certainly, the 
epidemic and ecological factors and characteristics of plant pathogens played a key role in determining the successful use of biological control agents. The environmental conditions like high humidity, temperature, nutrients and incubation period enhances the rate of infection on host and in addition the susceptibility of the host plant and the virulence of the pathogen significantly increased the rate of infection. The increase of incubation time offers the favourable conditions for spore germination and the development infection structures and mycelial development. The Gibbago (pathogen) - Trianthema (host) pathosystem revealed the virulence of the pathogen as a mycoherbicide to the host which causes severe endemic on leaves, petioles, stem and other propagules of the weed plant (Fig.4). The early stage of the weed plant with 3-6 foliage, favours the germination and penetration of germ tube or appressorium, the infective propagules of the pathogen.

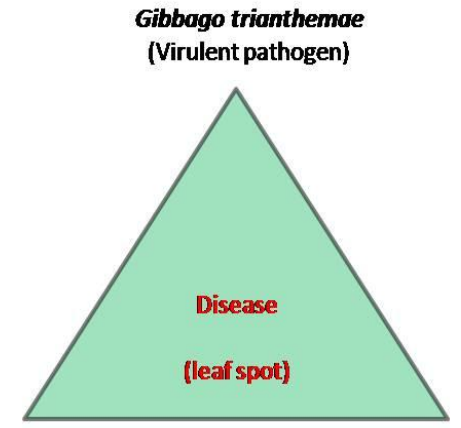

Trianthema portulacastrum L. (Susceptible host)
Favourable environment (Temperature and high humidity)
Fig.4: Diagrammatic representation of host- pathogen interaction

The destructive damage of leaves and stems was examined on the susceptible stage of the weed and causes $100 \%$ mortality of the weed within a short period. Stained sections of infected leaves revealed the germination of conidia and the penetration of the pathogen into host tissue by means of infection structures, appressoria. The plant tissue at the infected site collapsed and extensive ramification of the hyphae examined in host leaf tissue under light microscopy. The study suggested that many factors should be considered to evaluate Gibbago trianthemae pathosystem.

\section{CONCLUSION}

A total of six fungal species viz., A. alternata, C. capsici, B. maydis, C. lunata, $\quad$ C. tuberculata and G. trianthemae were isolated and identified on infected parts of

$T$. portulacastrum (horse purslane), which was the dominant weed in many agricultural crops in study area. The isolates namely $A$. alternata and $B$. maydis were shown moderate symptoms on host plant while the pathogenicity of other species such as C. capsici, $C$. lunata and $C$. tuberculata was not recorded and they were considered as non pathogenic fungi to horse purslane weed. Our findings revealed that $G$. trianthemae caused severe infection on host weed within short span of time. Our study suggested that $G$. trianthemae to be a potential agent to horse purslane and the extensive work in field conditions was needed to justify the virulence of the pathogen on host weed. We reported the primary information on pathogenicity of $G$. trianthemae against $T$. portulacastrum at crop fields of Visakhapatnam District and the extensive study on host range, the host-pathogen interaction, infection process, growth and sporulation, mass culture and compatibility with various pesticides is needed for the development $G$. trianthemae as an effective mycoherbicide.

\section{ACKNOWLEDGEMENTS}

We gratefully acknowledged to the University Grants Commission, New Delhi, the Government of India, for the financial assistance under UGC-SAP-CAS in Department of Botany, Centre for Advanced Study, Andhra University, Visakhapatnam.

\section{REFERENCES}

1. Duthie JF. Flora of the Upper Gangetic Plain. Delhi, India: Periodical Experts. 1960

2. Jeffrey C. Notes on tropical African Aizoaceae. Kew Bull. 1960; 14: $235-238$

3. Jeffrey C. Aizoaceae (including Molluginaceae and Tetragoniaceae) In: Hubbard OBE, Milne-Redhead E, editors. Flora of Tropical East Africa. London, Crown Agents for Oversea Governments, 1961.

4. Adamson RS. The South African species of Aizoaceae, 12: Sesuvium, Trianthema, Zaleya. South African Journal of Botany. 1962; 28: 243- 253.

5. Holm L, Doll J, Holm E, Pancho J, Herberger J. World Weeds: Natural Histories and Distribution. New York: J. Wiley, 1997. 1129 p.

6. Nayyar MN, Ashiq M, Ahmad I. Manual on Punjab Weeds Directorate of Agronomy. Ayub Agricultural Institute, Faisalabad, Pakistan, 2001; 1:52.

7. Aneja KR, Khan SA, Kaushal S. Management of Horse purslane (Trianthema portulacastrum L.) with Gibbago trianthemae Simmons in India. In: Spencer NR, editor. Proceedings of the X International Symposium on Biological Control of Weeds. Montana State University, Bozeman, Montana, USA. 2000; 27-33.

8. Charudattan R. The mycoherbicide approach with plant pathogens. In: TeBeest DO, editor. Microbial control of weeds. Chapman \& Hall, NY. 1991; 24-57.

9. Bohra B, Vyas BN, Godrej NB, Mistry KB. Evaluation of Alternaria alternate (Fr.) Keissler for biological control of Trianthema portulacastrum L. Indian Phytopathology. 2005; 58 (2): 184-188.

10. Boyette CD, Hoagland RE, Abbas HK. Evaluation of the bioherbicide Myrothecium verrucaria for weed control in tomato (Lycopersicon esculentum). Biocontrol Science and Technology. 2007; 17:171- 178.

11. Aneja K R. Experiments in Microbiology, Plant Pathology and Biotechnology. $4^{\text {th }}$ Edn., New Age International publishers, New Delhi. 2003;120 p.

12. Barnett HL. Illustrated genera of imperfect fungi. 2nd ed. Minneapolis, MN: Burgess Publishing Company.1960; p225.

13. Barron, GL. The genera of hyphomycetes from soil. The Williams \& Wilkins Company, Baltimore, USA. 1968.

14. Domsch KH, Gams W, Anderson TH, Compendium of Soil Fungi. Eching, Germany, IHW-Verlag.2007; p.672.

15. Ellis MB, Dematiaceous Hyphomycetes. CMI, Kew, England. 1971; p.608.

16. Ellis MB.More dermatiaceous hypomycetes. Kew, Surrey, UK, Commonwealth Mycological Institute. 1976; p. 507. 
17. Gilman JC. A Manual of Soil Fungi. The Iowa State University Press, USA.1957.

18. Holliday P. A Dictionary of Plant Pathogens. New Delhi, India: Cambridge University Press. 1993; p.369.

19. Nagamani A, Kunwar IK, Manoharachary C. Hand book of soil fungi. I.K. International Pvt. Ltd. 2006.

20. Sivanesan A. Graminicolous species of Bipolaris, Curvularia, Drechslera, Exserohilum and their teleomorphs. Kew, Surrey, U.K., Commonwealth Mycological Institute Mycological Paper. 1987; p.158.

21. Sutton BC. The Coelomycetes: Fungi Imperfect with Pycnidia, Acervuli and Stromata. Kew, Surrey, U.K., Commonwealth Mycological Institute.1980; p.696.

22. Simmons EG. Gibbago, a new phaeodictyoconidial genus of hyphomycetes. Mycotaxon. 1986; 27:107-111.

23. Mitchell JK. Gibbago trianthemae, a recently described hyphomycetes with bioherbicide potential for the control of horse purslane (Trianthema portulacastrum). Plant Disease Notes. 1988; 72: 354-355.
24. Aneja KR, Kaushal S. Occurrence of Gibbago trianthemae on horse purslane in India. Journal of Biological Control. 1998; 12:157-159.

25. Parimala Devi P, Marimuthu P. Effect of botanical formulation of Polygonum minus (P-40) on control of Alternaria Solani. Journal of Plant Pathology and Microbiology. 2011; 2:1

26. Hossain MT, Hossain SMM, Bakr MA, Matiar Rahman AKM, Uddin SN. Survey on major diseases of vegetable and fruit crops in Chittagong Region. Bangladesh Journal of Agricultural Research. 2010: 35(3): 423-429.

\section{How to cite this article:}

Gaddeyya G, Ratna Kumar PK, Bharathi P. Selection of some fungal pathogens for biological control of Trianthema portulacastrum L., a common weed of vegetable crops. J App Biol Biotech. 2016; 4 (04): 090-096. DOI: 10.7324/JABB.2016.40411 